\title{
SOCIAL CONTROL OF MISBEHAVIOR AMONG MUSLIM YOUTH IN BIMA DISTRICT, INDONESIA
}

\author{
Arlin Adam, Irman Susanto, Zainuddin \\ Senior Lecturers at Faculty of Public Health, \\ Universitas Pejuang Republik Indonesia (UPRI) Makassar \\ Jalan Gunung Bawakaraeng No.72, Lariang Bangi, Makassar, \\ Kota Makassar, Sulawesi Selatan 90151 \\ Email: arlin.adam73@gmail.com; susantoirman@gmail.com; \\ ymh_zainuddin@yahoo.co.id
}

\begin{abstract}
The main objectives of this study is to find out the mechanisms of social control are less able to control the deviant behavior of adolescents. Another thing might to be considered is to find out social control over juvenile deviant behavior. This study employs a qualitative descriptive approach with data collection techniques through observation, interviews and documentation. The research suggest that the mechanism of social control carried out by the police, religious leaders, traditional leaders, educator figures, community leaders and parents in controlling adolescent deviant behavior was relatively low in the form of social control in the form of persuasive and repressive actions. In addition, there is no form of cooperation between the government, the police and the community in controlling juvenile deviant behavior. Social control carried out by the police, religious leaders, traditional leaders, educator figures, community leaders and parents on the deviant behavior of adolescents in Monta Subdistrict, Bima Regency starts from coaching, socialization and reprimand. The social control mechanism that we can apply in adolescent deviant behavior is the cooperation of the government and the community in controlling juvenile deviant behavior
\end{abstract}


Keywords: Deviant Behavior, Social Control, Persuasive, Repressive.

\section{Introduction}

The proliferation of issues of moral degradation among adolescents such as the use of drugs, student brawls, pornography, consuming alcoholic beverages, consuming tramadol, free sex and so on, have become social problems that until now have not been overcome complete. The consequences are quite serious and can no longer be considered as a simple problem, because these actions have led to criminal acts. Adolescent association without direction and lack of supervision of their behavior will have a tendency towards negative relationships.

Lately there have been a number of cases that tarnished the name of the world of education, which shows that moral degradation and values among the younger generation we highlight today are the behavior of students or adolescents who have exceeded the corridors, which in fact they have goals that noble, which is to help educate the nation.

As time goes on, the actions taken by students or adolescents today are enough to worry us all as citizens who care about the sustainability of this nation. What is surprising is the behavior of generations in terms of students, on this day it is no longer ashamed to post photos that blend potnography with their partners, it has even become a showroom for other friends on social media. This means that the moral and values in adolescents today are not considered 
as a system that is considered as a prisai or procedure in living in a society.

According to the Indonesian National Commission for Child Protection (KPNAS) KPAI (in Syahratun Nadira. 2015: 2) published in okezone.com, it shows that the percentage of teenagers who have had premarital sex reached $62.7 \%, 21.2 \%$ of teenagers had had an abortion, $93.7 \%$ of middle and high school adolescents had kissed and oral sex, 97.0\% of junior and senior high school teens had watched pornographic films.

According to Tahir G (2011: 1) the current condition of Indonesian adolescents can be described as follows: marriage of teenagers, premarital sex and unwanted pregnancy, abortion 2.4 million (700-800 thousand are teenagers), (17,000 / year, 1417 / month, 47 / day of female death) due to complications of pregnancy and childbirth, infected with HIV / AIDS an estimated 52,000 people (70\% are teenagers).

While according to the research results of Mataram Husada Medical Polytechnic campus that was published in (metromini.co.id) that $27.32 \%$ of drug users were students throughout Bima District. This number includes critical figures, so it must be a special attention of the local government to carry out prevention. While according to data held by Bima Binmas Police Unit, currently there are 5 percent of drug users in Tonggorisa Village who are students.

Meanwhile, according to the head of the health department posted in (Suara NTB.com) at least 405 teenagers were sent to the soul hospital (KSJ) Mutiara sukma, mataram. Hundreds of adolescents were detected having a neurological 
disorder due to taking hard drugs of the type Tramadol. While the data that was signaled by the Bima LPEPM Child Social Welfare Institution (LKSA) was published in (bimakini.com), that $25 \%$ of those who consumed tramadol were students and 24 years and under. In fact, one school was based on a report from the BNNK in Kabupaten Bima after an interview was tested from 57 students, 50 of whom consumed tramadol. Even among adolescents the use of illegal drugs (tramdol) is not done secretly anymore, as if this behavior has become commonplace, not only teenagers, even students as an easy generation who have a noble task are not spared from the consumption of tramadol.

Meanwhile, one of the online media in Bima, online (bimakini.com) reported that the subdistrict side of the district of Bima on February 09 successfully raided several alcoholic drugs and illegal drugs such as tramadol and the like.

The effects of this abuse of tramadol type hard drugs physically can interfere with kidney function, damage the central nervous system, and provide drug dependence. While we can see psychological or mental effects where teenagers who often consume tramadol behave uncharacteristically like, like angry, for obvious reasons. Not infrequently the trigger for brawls between students or adolescents is generally triggered by the effects of tramadol.

While reports from Bima district $\mathrm{BNN}$ are based on data on drug misuse included in drug $G$ in 2017. It shows that noble age $15-25$ years $16 \%, 26-35$ years $13 \%$, 36-40 years $5 \%$, 40 years $3 \%$. Of the types of drugs used are 
methamphetamine $18 \%$, marijuana $2 \%$, tramadol $16 \%$, morphy $1 \%$. While the choice of clian characteristics based on status are: private $8 \%$, not working $10 \%$, self-employed $11 \%$, students 4\% PNS 1\%, and students 3\%.

While data from the Bima Tahu District Social Service 2017 reported 10 teenagers who committed deviant behavior in the Monta sub-district. Each of the 10 performs various forms of deviant behavior, starting from theft, destruction, sexual abuse, snatching, and abuse of tramadol drugs.

It can all occur because of negligence in carrying out the social control function that should be able to be tackled before teenagers do these things. This means that the government has not been able to optimally, in carrying out social control of violations of violations committed by adolescents which lead to deviant behavior. In addition, this is a failure of parents to supervise their children, where they rarely care about how their children interact in the community. Even their assumption is the absolute duty of the school in carrying out the task of educating its children. So that deviant behavior is born from the ignorance of adolescent parents, especially students in general. Apart from that, there is a lack of supervision of the local community in carrying out social control of adolescents who behave deviant.

For this reason, the government needs to make policies regarding rules and regulations relating to the formation of adolescent behavior as well as a means of social control so that negative influences from outside can be avoided. With the existence of a good regulation or system and agreed upon 
by all parties, namely the government and society, it is expected that violations that lead to deviant behavior can be controlled.

With the help of social control over the deviant behavior of the Bima Regency adolescents, it is expected that young people who are disciplined and responsible will be formed, so that problems of moral violations that often occur such as fighting, carrying drugs (tramadol), consuming alcohol and so on can be reduced to a minimum . To realize all that, there needs to be a special formula so that social control can be carried out effectively and efficiently. with good rules of conduct and social control that have been agreed upon by all elements of the government, it is also carried out correctly, it is expected to create a conducive situation and condition in Bima Regency.

\section{Functional Structural Concept}

In the perspective of juvenile delinquency social problems occur because there are behavioral deviations from various rules or from prevailing social values and norms. Deviant behavior can be considered as a source of social problems because it can endanger a social system.

Structural functional theory is developed dominantly in family studies. This theory sees society as a dynamic system consisting of various subsystems that are interconnected with one another. Functional theory views that all subsystems have consequences for others and also for the system as a whole. 


\section{Functional Structural Theory According to Talcon Parsons}

According to functional structural theory, as proposed by Parsons, the community will be in a harmonious state and balanced if the institutions or institutions that exist in society and the state are able to maintain stability in the community.

A function (fungction) is a collection of activities aimed at fulfilling certain needs or system requirements (R. Stryker, 2007, Roche, 1975, In George 2014: 117). By using this method, parsons believes that there are four important functions needed by all systems, including:

a) Adaptation: a system must overcome a severe external situation. The system must adapt to the environment and adjust the environment according to needs.

b) Goal attament: a system must define and achieve the main goal.

c) Integration (integration): a system must regulate the interrelationships of the parts that become its components. The system must also process the relationships between the three other important functions (A, G, I).

d) Latency (latency or pattern maintenance): a system must equip, maintain and improve both individual motivation and cultural patterns that create and sustain motivation.

\section{Social Control Concept}

Social control (social control) is as all processes, both planned and unplanned, whether educating, inviting or even forcing citizens to comply with prevailing rules and social 
values (Roucek in Setiadi and Kolip, 2011: 252) . Social control is also not only educational, inviting or even compelling, but social control (social control) in everyday life is interpreted as supervision by the public of government nets, especially the government and its apparatus, Soekanto (Akbar, 2011: 10).

But in a broader sense the term control does not only revolve around the supervision of the public on the course of government but also the methods used to encourage someone to behave in harmony with the wishes of the group or the general public in general (Cohen in Setiadi and Kolip, 2011: 252) .

So social control is an oversight carried out both from the government and the community in general to monitor, direct or control the behavior of individuals or groups that commit deviant behavior or that emerge from the values and norms that apply in the community in order to create a social situation expected together. Both those that are educational, inviting, or even compelling to comply with the rules and values that apply in society

\section{Forms of Forms of Social Control}

Roucek (akbar, 2011: 12) provides an overview of how social control can be done through:

a. Institutional and non-institutional social controls Social control through institutions is a way of social control through social institutions in society, such as educational, religious, political and family institutions. Social control through educational institutions such as schools, 
informal and non-formal education, namely education outside of school, someone directed his behavior to be in accordance with the demands of social rules that apply in society. Through educational institutions, someone learns things that are pleasing to knowledge (cognitive) about attitudes that include values, norms, ethics and art (effective) and the skills that support so that he is able to behave naturally.

Social control through religious teachings can be done by emphasizing the teachings of the religion about holy truth according to their respective adherents. Wisdom, wisdom and devotion to the rulers of the universe are the most important points in the teachings of each religion. The teachings of religion have absolute sanctions, meaning that everyone will receive a proper punishment if they violate His teachings and no one will escape the divine trial.

\section{b. Oral, Symbolic and Violent Social Control}

The way of social control through oral and symbolic is often also called the way of persuasive social control. This method emphasizes efforts to invite or guide community members to be able to act in accordance with applicable rules. Oral social control is carried out by inviting people to obey the rules by speaking directly with verbal language. While symbolic social control can be done with writing, banners, and public service advertisements. How to control through violence can also be called coercive social control, which is a way of social control by emphasizing actions or threats that use physical strength so that the perpetrator feels deterrent and does not repeat the deviations he has committed. 
c. Social Control With Punishment

The way social control through rewards tends to be perventive (multiplying). A person is rewarded for his actions so that he behaves in accordance with applicable values and norms. Whereas the way social control can be through punishment tends to be repressive in nature that aims to restore conditions like before the occurrence of irregularities.

d. Formal Social Control and Informal Control

Formal control means carried out by institutions that are official or recognized as being at least for individuals or groups that commit or do not commit violations of rules, such as police and penal institutions. The process of informal social control can be carried out through small groups, familiar, informal and do not have written official rules. It is generally done by people with perpetrators of deviations, such as close friends, close friends and games.

We can conclude that forms of social control both use institutional and non-institutional social controls, verbal social control, symbolic, violence, social control with law and social control in formal and informal ways is a way to control the behavior of individuals or community groups that commit deviant behavior.

\section{Social control agent}

Control (social control) is needed so that the life of socialization in the community is harmoniously intertwined, and reduces the occurrence of social deviations carried out by 
individuals or groups. The agents who can implement social control include:

a. Family

Harton and Hunt (1996) in Hamzah (2015: 2) define that, the family is the first primary group of a child and that is where personality development begins. When a child is old enough to enter another primary group outside the family, the basic foundation of his personality has been directed and formed.

b. Culture

Customs are social actions in the community that still adhere to the ongoing cultural traditions. Community members who violate customs / traditions will be subject to sanctions, these sanctions can be excluded from the surrounding community. (Soekanto, Soerjono, 1988, In Narwoko J. Dwi Bagong Suyanto, 2011) in Alias, Fatmawati, Mochtaria (2013: 4).

c. Law Enforcement Institution

Law enforcement agencies in our country are courts, prosecutors and police. This institution is formally assigned its duties and functions in the law. However, if we look at the tasks and functions it turns out that it has a positive impact as social control or social control (Wahyuni, 2004).

d. Educational institutions

Educational institutions have a large share of participation in social control institutions, especially for students and generally in all levels of education. Nasution (2010: 18) notes that direct control in schools comes from school principals and teachers. They are the ones who determine how the students behave. When children violate regulations, teachers 
can use the authority to take action against the student so they won't repeat it.

e. Religion institution

Religious institutions are important religious beliefs and practices from the community that have been carried out and have been widely formulated and adopted and are seen as necessary and correct (Hrton and Hunt, 1996) in Hamzah (2015: 3). Religious institutions are often convinced by society to be a very effective agent of social c Dick to reduce, control the amount of shedding behavior in the midst of an increasingly complex society. Because religious teachings themselves are values and norms whose values are also adopted by law in making certain rules in overcoming the many deviant behaviors in society.

\section{f. Community Institution}

The existence of social institutions such as, RT, RW, LKMD (Village Community Resilience Institution), BPD (Village Representative Body) and BKM (Community SelfSufficiency Agency) in increasingly complex people's lives is very important, because this institution is a social control institution at the most under. Through influential, authoritative figures, it is believed that this is the case, social problems are mostly resolved by the community itself (Wahyuni, 2004).

\section{The Concept of Misbehaviour}

1) Setiadi and Kolip (2011: 187), say that deviant behavior is the behavior of citizens who are considered not in 
accordance with the habits, rules or social norms that apply. While Kartono in Mantiri (2014: 4), deviant behavior is an act that violates the norms, rules or laws in society that are carried out in adolescence or the transition of childhood and adulthood.

2) The behavior of saving is an action that is consciously carried out by the culprit, even though he knows what is done is wrong. And also known as social deviation is behavior that is not in accordance with the values of decency or obedience, both in the standpoint of humanity individually and as a part of social beings (Rahmadani In Jamal 2015: 11).

3) So deviant behavior is an action carried out by adolescents or adults who are considered to violate the rules or values, norms that apply in society by consciously.

\section{Forms of Deviant Behavior}

According to Kartono (2014 :) juvenile delinquency behavior can be divided into four, namely:

1) Delinquency is isolated (isolated delinquency), this group is the largest number of juvenile delinquents. In general they do not suffer psychological damage.

2) Neurotic delinquency (neurotic delenence), in general, delinquency delinquents of this type suffer from psychiatric disorders that are quite serious, including anxiety, feeling insecure, feeling guilty and sinful and so on. 
3) Psychopathic delinquency (psychopathic delenence), these psychopathic delinquencies are few in number, but seen from the public interest and in terms of security, they are the most dangerous criminal elements.

4) Delinquency in moral defects (delenkuensi moral defects), meaning, broken, not dark, wrong, injured, disabled, lacking. They are quickly satisfied with their achievements, but their actions are often accompanied by explosive aggressiveness. Teenagers whose moral defects are usually criminals are difficult to repair.

\section{Research Method}

1. Type of Research

This type of research is qualitative research with a qualitativedescriptive approach. Moleong (2014: 19) argues that qualitative research is research whose data is in the form of written words, descriptions obtained from informants, and behavior of the subjects observed. This research refers to research procedures that produce descriptive data, namely what is done fundamentally and told by informants, both oral and written.

2. Location of the study

This research was carried out in Kabupaten Bima on the grounds that: (a) Social control carried out by the government did not have an effect on violators which facilitated the proliferation of juvenile deviant behavior in the community, (b) The number of violations committed by teenagers in Bima Regency. 


\section{Focus of Research}

The focus of this study is social control of adolescent deviant behavior, social control mechanisms in controlling juvenile deviant behavior, forms of social control against irregularities, alternative forms of social control that can be applied to minimize deviations.

\section{Description of Research Focus}

To facilitate the observation of the focus of the study, this study focuses on the form of social control on the deviant behavior of adolescents in Kabupaten Bima, including:

1. The form of social control of deviant behavior in adolescents is a rule that is deliberately made by the command to regulate or control the behavior of adolescents in accordance with applicable regulations.

2. The mechanism of social control is the order of a system or the rules of an institution in controlling juvenile deviant behavior.

3. What kind of social control mechanism can be applied in controlling adolescent deviant behavior is cooperation between elements of the government and the community in conducting supervision related to the deviant behavior of adolescents.

\section{Research Instrument}

The instrument in this research is the researchers themselves with the help of equipment such as interview 
guides, observation guides, and documentation guides as tools in obtaining data in the field.

\section{Research Subjects}

In determining the research subject or respondent as an informant, the first subject was chosen as the key informant, that is, informants based on certain considerations fulfilled the requirements as informants who were very aware of the problems to be studied. In this case, those who are considered to meet the requirements of knowing the substance of behavior that intersects the adolescents of Kabupaten Bima are the police, community institutions (religious leaders, traditional leaders, educational figures, community leaders) and parents. In determining the respondent was done by purposive sampling technique. Purposive sampling is a technique of sampling data sources with certain considerations, namely informants who have credible positions in the community where their role has been to control the social life of the community.

\section{Technique of Collection and Presentation}

To facilitate collecting data needed, the data collection techniques used in this study were interviews, observation, documentation, and discussion with the FGD method.

The presentation of data is done in the form of narratives, meaning that the researcher narrates and provides interpretations of the phenomena that are explored in the field. The development of narratives is based on 
interpretations of the centers of meaning that control every phenomenon or fact of the field.

\section{Findings and Discussions}

All societies and social groups have mechanisms to ensure conformity to norms which are referred to as social control mechanisms. Social control means the processes and methods used by members of a society or a group to maintain order or social order by enforcing deviant behavior by the teenager, which is meant by the mechanism of social control in this case is a way - how to force community members to conform. This means that people are forced to behave in accordance with the values and norms that apply in the structure of the community. In addition, what needs to be considered is which party does the control, whether it is an official or unofficial social control institution. This certainly will greatly affect the effectiveness of the power of binding in binding to social behavior.

However, the non-functioning of community institutions in controlling adolescent deviant behavior is less effective so that mechanisms of social control such as through adat, beliefs, traditions, attitudes, and values are not able to control adolescent deviant behavior. So that it will have an impact on the behavior of adolescents which are increasingly worrisome.

While the results of the study show that the mechanism of social control is less able to control adolescent deviant behavior because social control institutions do not function, 
both internally and externally, both formal institutions and non-formal institutions. In addition, the presence of apathy or a sense of indifference to the community towards adolescent deviant behavior, not to mention added with a less strict mechanism of social control applied by existing institutions. This condition is exacerbated by the punishment for adolescents who commit deviant behaviors only by the police alone. At least what needs to be applied in this case is coercive / repressive social control.

Indifference and without effective social control The result of adolescents' behavior is increasing, such as stealing, brawls, the use of illegal drugs such as tramadol. With the non-functioning of social control institutions, the community will experience chaos because actually in the community there is a chain of systems for creating order as a mechanism that guarantees a homeostatic situation.

In addition, this study also found that the role of the police as law enforcement agencies did not function clearly in applying the applicable rules. There seems to be an apathy towards the situation that has the potential to disrupt the orderliness and security of life together.

The role of family institutions in constructing deviant behaviors is also relatively low and can even be said to tend to support because generally parents show angry reactions when their children are reprimanded by interested parties due to deviant behavior. This shows the fact that there are less social control institutions that show synergy. 
The basic reason for the lack of effective social control is that almost no sanctions are given by the government and the police in carrying out their duties and responsibilities as law enforcers. Where the police only give a rebuke when getting children or adolescents who commit deviant behavior, such as stealing, brawls, liquor, abuse of tramadol drugs and the potential for other social disorders.

The form of social control in the form of reprimand turns out to be unable to solve a problem that occurs in the community. The police often use a "peaceful" method by giving compensation to the injured party. This is what causes the weakening of social control towards the deviant behavior of adolescents in this research area. The implication is that this practice provides an opportunity for community members to disobey the rules that apply in the community. Some people assume that any violations committed will ultimately be settled peacefully.

Another fact is that the livelihoods of the majority of the people who make social control over the deviant behavior of adolescents are less effective because parents spend more time in the fields or in the garden than with their children. This is one of the causes of the weakening of social control towards adolescents. Togetherness of parents with their children is increasingly stretched by the influence of modernization of life among adolescents who easily adopt outside cultural patterns without adequate infiltration of local values. 
Social control is an effort to control the behavior of the community that violates the norms, values that apply in society which leads to deviant behavior. Social control is needed in every social life considering the pattern of relations between members of the community always occurs two possibilities, namely the pattern of adjustment to values and norms and incompatibility with values and norms.

The pattern of relationships that can adjust to these values and norms will form social order, while incompatibilities with values and norms form deviant behaviors that cause social disorder. In this situation, the existence of social control plays an important role to restore the behavior of members of the community who deviate in order to conform to the values and norms that apply.

In the life of a modern society, the most important party that is expected in an effort to uphold social norms while protecting other citizens from interference from people who intentionally or unintentionally violate the rules or applicable law is the police. The presence of the police in taking action against adolescents who commit irregularities has a strong legal force and umbrella. Therefore the police not only arrest, investigate and hand over the perpetrators of crime to legal institutions, but also play a role in fostering and providing information to people who behave deviant so as not to commit deviant behavior again.

In fact, sometimes the police try to control teenagers' deviant behavior optimally, but the number of personnel is 
very limited resulting in multiple tasks and responsibilities being carried out at the same time.

Social control by community groups in the Monta subdistrict in mapping the social control of the community is categorized in the form of social control through noninstitutions. This type of social control in groups is carried out if persuasive social control is not accepted by adolescents who commit deviant behavior. Sometimes perpetrators of deviant behavior are asked to abandon their habits but the teenagers refuse. The next mechanism is to bring together community leaders in an area to discuss together the anticipation of social violations. Usually such a mechanism is considered effective because decisions taken have the social power to control the sources of the causes of social chaos.

In addition, the socialization carried out by religious leaders in controlling juvenile deviant behavior is a form of prevention of adolescents related to deviant behavior. The socialization carried out by the religious leaders included in the nature of preventive social control. Preventive control is all forms of social control in the form of prevention of deviant behavior (devation) so that social life remains conducive (conformity).

Reprimands carried out by control actors such as traditional leaders, educator figures, and parents are social controls in a coercive form at a simple level because they only use spoken language as a form of controlling juvenile deviant behavior. 
The existence of social control is a consequence of deviant behavior. Reactions to deviant behaviors such as stealing, drinking liquor, and abuse of tramadol illegal drugs are violations of values and norms or rules. There is an impression that the existence of juvenile delinquency results from the imitation of the western lifestyle that has shifted the attitude of the east that upholds ethics in association and knows the boundaries of association. Therefore, in the concept of the eastern community as in the Monta sub-district does not tolerate juvenile delinquency in any form.

The attitude of community intolerance towards all forms of irregularities allows the community to sometimes take shortcuts through acts of violence against perpetrators of perverts. This method is taken only if all family methods have been taken, but have not found significant results.

In groups or communities with high cohesion where each other knows each other personally, the control mechanism is generally carried out directly by members of the community as a whole. The form can be a persuasive mechanism, laughing, gossiping, or insulting. In contrast to urban communities, community members are indifferent, individualistic, and do not want to interfere with other people's business, supervision of others has almost no power.

This study identifies informants' proposals about social control mechanisms that are effectively developed in research locations in controlling deviant behavior is a cooperative mechanism / collaboration between government institutions and social institutions. Government agencies effectively carry 
out formal legal controls, while effective social institutions use cultural values as the basis of control.

The above facts are in line with the delivery of informants from the police said that the synergy between existing institutions will accelerate the overcoming of deviant behavioral problems that are often practiced by teenagers.

The police also offer alternative social control behavioral deviations stemming from direct community participation to play an active role in controlling juvenile deviant behavior. Therefore a community empowerment intervention is needed through strengthening the capacity of community leaders in recognizing the symptoms of irregularities and in carrying out methods, approaches, and problem solving techniques.

Meanwhile religious leaders offer the development of creative activities for adolescents towards achievements that ensure that teenagers are not easily caught in risky behavior. This model of social control is often called a preventive approach. Preventive control is all forms of control in the form of prevention of deviant behavior so that social life remains conducive. Thus it is expected that juvenile delinquency in the research area can be minimized by the presence of innovative, creative, and prestigious activities.

Sometimes violence or coercion needs to be used in controlling juvenile deviant behavior. Because, using just reprimand in controlling adolescent deviant behavior is not enough to make teenagers who like to violate rules or values and norms. Therefore, the mechanism of social control that 
is no less effective in enforcing social order within the community is using physical violence.

For informants, social control that is truly effective as a social control to control juvenile deviant behavior is that the government is consistent in carrying out its duties and obligations and running a good system related to social control. Apart from that, the government tries to embrace institutions within the community to play a role in controlling deviant behavior.

By enforcing this system it is hoped that social control can control juvenile deviant behavior.

In addition, the social control that we can do in controlling adolescent deviant behavior is the active role of parents in monitoring their children's behavior patterns, especially those belonging to adolescents. Parents are obliged to take the time to apply an intensive, orderly and sustainable pattern of childcare so that the family continues to appear as an institution to maintain the values of goodness and honesty as the core fundamentals of a civilized society's life.

The specific role of parents is to control the social environment of the child, especially the social environment of peers or close friends. Because teenagers are more able to accept influences from close friends, both positive influences and negative influences.

\section{Concluding Remarks}

The mechanism of social control carried out by the police, religious leaders, traditional leaders, educator figures, 
community leaders and parents in controlling juvenile deviant behavior is relatively low. In addition, the lack of cooperation between the government, the police and the community in controlling juvenile deviant behavior further exacerbates the fertility of deviant behavior. Social control carried out by the police, religious leaders, traditional leaders, educator figures, community leaders and parents on the deviant behavior of adolescents in Monta Subdistrict, Bima Regency starts from guidance, socialization and reprimand.

The social control mechanism that we can implement in adolescent deviant behavior is the collaboration of government and community synergy in controlling juvenile deviant behavior.

\section{Bibliography}

Akbar M, 2011. Kontrol sosial terbadap pergaulan bebas pelajar di kecamatan bajeng kabupaten gowa. (Tesis, Universitas Negeri Makassar, Makassar, Indonesia).

Alias, Fatmawati, Mochtaria. 2013. Kontrol Sosial Tokoh Masyarakat (Ustad) Dalam Mengatasi Penyimpangan Perilaku Remaja Di Desa Limbung Kecamatan Sungai Raya. Kabupaten Kubu Raya. Jurnal Tesis PMISUNTAN-PSS-

Dean J. Champion, James A. Black. 1999. Metode dan masalah penelitian sosial. Bandung. PT Rafika Aditama. 
Gunawan Ary. H. 2000. Sosiologi Pendidikan Suatu Analisis Sosiologi Tentng Pelbagai Problem Pendidikan. PT Rineka Cipta: Jakarta.

Hamza. M. 2015. Peran konrol sosial dalam pengendalian perilaku mahasiswa kos sekitar kampus universitas mulawarman samarinda. Ejournal 3 (2), 124-137.

Kartono Kartini. 2014. Patologi Sosial Jilid 1. Rajawali Pers: Jakarta.

Mantiri Vike Vive. 2014. Perilaku Menyimpang Dilakalangan Remajadi Kelurahan Pondang, Kecamatan Amurangtimur Kabupaten Minahasa Selatan. Jurnal volume III. No. 1. tahun 2014.

Moleong, Lexy. 2014. Metodologi Penelitian Kualitatif. Bandung: PT Remaja.

Narwoko Dwi. J \& Suyanto Bagong. 2007. Sosiologi Teks Pengantar Dan Terapan Edisi Kedua. Jakarta : kencana

Nasution, Noehi, dkk. 2010. Psikologi Pendidikan. Jakarta: Dikti, Depdikbud

Ritzer George. 2014. Teori Sosiologi Modern Edisi Ketujuh. Prenadamedia Group. Jakarta.

Setiadi M. Elly, Kolip Usman. 2011. pengantar sosiologi, pemahaman fakta dan gejala. pemasalah soial: teori, aplikasi, dan pemecaban. Edisi 1. Jakarta: kencana media group.

Sidi Purnomo. 2014. Krisis Karakter Dalam Perspektif Teori Struktural Fungsional. Jurnal Pembanguan Pendidikan: Fondasi Dan Aplikasi. 
Syahratunnadirah. 2015. Pengerub Pendidikan Karakter Dalam Menanggulangi Delinquency Siswa (Studi Kasus Di Sma Negeri 1 Makassar). Skripsi, Universitas Negeri Makassar, Makassar, Indonesia.

Tahir G Muhammad H. 2011. Kenakalan Remaja (Studi Kasus Di Kota Makassar). (Disertasi, Universitas Negeri Makassar, Makassar, Indonesia).

www.bimakini.com. Razia Siswa Keluyuran, Senpi Dan Nak Panah Di Sita Pol PP. Di akses pada tanggal 4/12/2017. Jam 11:00.

http://www.suarantb.com/news/2017/07/27/242665/Kot a.Bima.Darurat.Tramadol,405.Remaja.Dirawat.di.RSJ . Di akses pada tanggal 17/12/2017. Jam 17:38. 